\title{
Phenolic profile and biological properties of the leaves of Ficus vasta Forssk. (Moraceae) growing in Egypt
}

\author{
Maria Fernanda Taviano ${ }^{1 *}$, Khaled Rashed ${ }^{2}$, Angela Filocamo ${ }^{3,1}$, Francesco Cacciola ${ }^{4}$, Paola Dugo 1,5,6, \\ Luigi Mondello ${ }^{1,5,6}$, Carlo Bisignano ${ }^{4}$, Rosaria Acquaviva ${ }^{7}$, Manuela D'Arrigo ${ }^{1}$ and Natalizia Miceli ${ }^{1+}$
}

\begin{abstract}
Background: Ficus vasta Forssk. (Moraceae) is traditionally used for the treatment of various ailments; nonetheless, this species has been poorly studied to date. This work aimed to characterize the phenolic profile and to evaluate the antioxidant and antimicrobial properties of a hydroalcoholic extract obtained from F. vasta leaves collected in Egypt.
\end{abstract}

Methods: The phenolic profile of the extract was characterized by HPLC-PDA/ESI-MS. The antioxidant properties were examined by different in vitro systems: DPPH test, reducing power and metal chelating activity assays. Moreover, the ability of the extract to protect Escherichia coli growth and survival from $\mathrm{H}_{2} \mathrm{O}_{2}$-induced oxidative stress was evaluated. The potential toxicity was investigated using Artemia salina lethality bioassay. Finally, the antimicrobial properties against a representative set of Gram-positive and Gram-negative bacterial strains and the yeast C. albicans were assayed by standard methods.

Results: By HPLC-PDA/ESI-MS analysis 12 compounds belonging to the groups of phenolic acids and flavonoids were identified. The extract exhibited strong radical scavenging activity in DPPH test $\left(I C_{50}=0.0672 \pm 0.0038 \mathrm{mg} /\right.$ $\mathrm{mL})$, reducing power $(3.65 \pm 0.48 \mathrm{ASE} / \mathrm{mL})$ and chelating activity $\left(\mathrm{IC}_{50}=0.801 \pm 0.007 \mathrm{mg} / \mathrm{mL}\right)$. A total protection against $\mathrm{H}_{2} \mathrm{O}_{2}$-induced damage on $\mathrm{E}$. coli was observed. No toxicity against $A$. salina was found $\left(\mathrm{LC}_{50}>1000 \mu \mathrm{g} / \mathrm{mL}\right)$. The extract exhibited bacteriostatic activity against almost all the bacteria tested (MICs: 250-62.5 $\mathrm{\mu g} / \mathrm{mL}$ ).

Conclusions: The obtained results demonstrate the potential of $F$. vasta leaves as safe sources of natural antioxidant and antimicrobial compounds.

Keywords: Ficus vasta Forssk., Phenolic profile, Antioxidant activity, Oxidative stress in Escherichia coli, Antimicrobial activity, Artemia salina Leach

\section{Background}

Medicinal plants are considered as potential sources for drug development and many novel products. Nonetheless, such plants should be investigated to better understand their properties, safety, and efficiency. Currently, many researchers are looking for newer, effective, and safe antioxidants, in order to use them in foods and pharmaceutical preparations to replace the synthetic

\footnotetext{
* Correspondence: mtaviano@unime.it

${ }^{\dagger}$ Equal contributors

${ }^{1}$ Dipartimento di Scienze Chimiche, Biologiche, Farmaceutiche ed Ambientali, University of Messina, Polo Annunziata, Viale Annunziata, 98168 Messina, Italy Full list of author information is available at the end of the article
}

ones, which have been reported to be dangerous for human health. Medicinal plants are the major source of chemical compounds exhibiting antioxidant activity. Particularly, a direct relationship between antioxidant activity and phenolic compounds has been demonstrated in many studies [1-4].

Recently, there is an increased frequency of multiple drug resistance in human pathogenic microorganism due to indiscriminate use of commercial antimicrobial drugs commonly used to treat various diseases. Therefore, there is an interest in developing alternative antimicrobial drugs for the treatment of infections obtained from various sources such as medicinal plants. Phytochemicals have

(c) The Author(s). 2018 Open Access This article is distributed under the terms of the Creative Commons Attribution 4.0 International License (http://creativecommons.org/licenses/by/4.0/), which permits unrestricted use, distribution, and reproduction in any medium, provided you give appropriate credit to the original author(s) and the source, provide a link to the Creative Commons license, and indicate if changes were made. The Creative Commons Public Domain Dedication waiver (http://creativecommons.org/publicdomain/zero/1.0/) applies to the data made available in this article, unless otherwise stated. 
become the target of a great number of researches focused on the discovery of potentially safe and effective antimicrobials. Plant based antimicrobials either unaided or in combination with antibiotics may be an effective approach to deal with the global antimicrobial resistance. Among plant bioactive compounds, polyphenols are well documented to have microbicide activities against a great number of pathogenic bacteria [5].

The genus Ficus L. (Moraceae) comprises about 800 species and 2000 varieties of woody trees, shrubs and vines known as fig trees [6]. Several members of this genus are being used in folk medicine all over the world for a wide range of ailments of the gastrointestinal tract, central nervous, endocrine, and reproductive systems, as well as infectious disorders like tuberculosis, respiratory and skin diseases [7-9].

Ficus vasta Forssk. is a very large tree growing over $25 \mathrm{~m}$ tall, with spreading rounded crown. Leaves are alternate, spirally arranged, quite stiff, rough to the touch, almost circular $(8-25 \times 4-23 \mathrm{~cm})$, margin entire, tip rounded but often with a blunt point, base rounded, heart shaped; usually glabrescent above, glabrescent, puberulous, hirsute or velutinous below [10].

This species is widespread throughout the dry north and eastern Africa, Sudan, Ethiopia, Saudi Arabia, Uganda and Tanzania. In Sudan the poultice of burned F. vasta leaves and barks was used as anti-tumor [11]. The leaves are traditionally used for the treatment of rheumatisms, pains and intestinal worms [12].

Although many species from the genus Ficus were subjected to phytochemical and pharmacological investigations, to the best of our information $F$. vasta has been poorly studied to date. Qualitative preliminary phytochemical analysis of Egyptian F. vasta leaves, using standard chemical tests, revealed the presence of carbohydrates, tannins, flavonoids, coumarins, and triterpenes [12]. Moreover, various phytoconstituents such as $\beta$-sitosterol, stigmasterol, lupeol, ursolic acid and some flavonoids were isolated and identified from $F$. vasta aerial parts [13]. Concerning biological activities, very few studies have been carried out on the leaves of this species $[10,14]$.

Thus, the present work was undertaken to characterize the phenolic profile and to investigate the antioxidant and antimicrobial properties of a hydroalcoholic extract obtained from the leaves of $F$. vasta collected in Egypt, never studied before.

\section{Methods}

\section{Chemicals and reagents}

LC-MS grade water $\left(\mathrm{H}_{2} \mathrm{O}\right)$, acetonitrile $(\mathrm{ACN})$, gallic acid, catechin, naringenin, chlorogenic acid, apigenin, rutin, kaempferol and quercetin were obtained from Merck KGaA (Darmstadt, Germany). LC-MS grade acetic acid was attained from Riedel-de Haën (Seelze, Germany); methanol $(\mathrm{MeOH})$ from Baker Analysed Reagent; Ferrous chloride $\left(\mathrm{FeCl}_{2}\right)$ was obtained from Carlo Erba (Milan, Italy). Müeller Hinton Broth (MHB), Sabouraud Dextrose Agar (SDA), and Luria-Bertani (LB) broth medium were supplied from Oxoid (Basingstoke, UK), RPMI 1640 from Gibco Laboratories (Grand Island, NY). Unless indicated otherwise, all chemicals were purchased from SigmaAldrich (Milan, Italy).

\section{Plant material and extraction procedure}

Ficus vasta leaves were collected in May from AlZohiriya garden, Giza, Egypt. The plant was identified by Dr. Mohammed El-Gebaly, Department of Botany, National Research Centre (NRC) and by Mrs. Tereeza Labib, consultant of Plant Taxonomy at the Ministry of Agriculture and director of Orman Botanical Garden, Giza, Egypt. A voucher specimen was deposited in the herbarium of Al-Zohiriya garden, Giza, Egypt, under accession number $\mathrm{n}^{\circ} \mathrm{FN}-2604$.

The air dried and powdered F. vasta leaves (200 g) were extracted with $80 \% \mathrm{MeOH}$ at room temperature several times under continuous shaking until exhaustion by maceration process. The extractive solutions were pooled, filtrated, and evaporated to dryness by rotary evaporator $\left(40^{\circ} \mathrm{C}\right)$. The yield of $F$. vasta extract, referred to $100 \mathrm{~g}$ of dried leaves, was $13.00 \%$.

\section{Phytochemical investigations \\ Identification of flavonoid compounds by paper chromatography}

F. vasta hydroalcoholic extract was subjected to paper chromatography (Whatman No.1) using three different solvent systems as n-butanol:acetic acid:water (BAW 4:1: 5, upper layer), $15 \%$ acetic acid, and water. By comparison with standard compounds some flavonoids were identified. Then, each band was cut, and the compounds were dissolved in a mixture of $\mathrm{MeOH} / \mathrm{H}_{2} \mathrm{O}$, purified over Sephadex LH-20 and identified by UV, ${ }^{1} \mathrm{H}-\mathrm{NMR}$ and MS analyses [15, 16].

\section{Identification of phenolic compounds by HPLC-PDA/ESI-MS}

HPLC-PDA/ESI-MS analyses were performed on a Prominence LC system (Shimadzu, Milan, Italy) equipped with photo diode array (PDA) and mass spectrometry (MS) (LCMS-2020, Shimadzu) detection. Data acquisition was performed by Shimadzu LabSolution software ver. 5.53 .

For chromatographic separations, an Ascentis Express C18 column $(15 \mathrm{~cm} \times 4.6 \mathrm{~mm}$ I.D. $)$ packed with $2.7 \mu \mathrm{m}$ partially porous particles, was employed (Supelco, Bellefonte, PA, USA). The injection volume was $5 \mu \mathrm{L}$, and the mobile phase consisted of water/acetic acid $(0.1 \%)$ at $\mathrm{pH}=3$ (solvent A) and ACN/acetic acid (0.1\%) (solvent B) 
, respectively in the following linear gradient mode: $0 \mathrm{~min}$, $0 \% \mathrm{~B} ; 5 \mathrm{~min}, 5 \% \mathrm{~B} ; 15 \mathrm{~min}, 10 \% \mathrm{~B} ; 30 \mathrm{~min}, 20 \% \mathrm{~B} ; 60 \mathrm{~min}$, $50 \% \mathrm{~B} ; 70 \mathrm{~min}, 100 \% \mathrm{~B} ; 71 \mathrm{~min}, 0 \% \mathrm{~B}$. The mobile phase flow rate was $1.0 \mathrm{~mL} / \mathrm{min}$, and it was splitted to $0.3 \mathrm{~mL} /$ min prior to MS detection. PDA wavelength range was 210-400 $\mathrm{nm}$ and the chromatograms were extracted at 280 and $350 \mathrm{~nm}$.

The extract $(10 \mathrm{mg})$ was dissolved in DMSO $(1 \mathrm{~mL})$ and filtered through a $0.45 \mu \mathrm{m}$ membrane filters (Whatman, Clifton, USA).

Phenolics identification was carried out by the complementary information provided by chromatographic retention times, PDA and mass spectra, and further supported by comparison to existing literature data [13].

The quantitative determination of each compound was carried out by means of the external standard method using gallic acid $(\lambda=270)$, catechin $(\lambda=278)$, naringenin $(\lambda=283)$, chlorogenic acid $(\lambda=325)$, apigenin $(\lambda=330)$, rutin $(\lambda=355)$, kaempferol $(\lambda=365)$ and quercetin $(\lambda=$ $370)$ as reference compounds in a concentration range of 1-100 ppm. With three different concentration levels. Triplicate injections were made for each level, and a linear regression was generated. The calibration curves with the external standards were obtained using concentration $(\mathrm{mg} / \mathrm{L})$ with respect to the area obtained from the integration of the PDA peaks at a wavelength of $270 \mathrm{~nm}$ for benzoic acid-like, $278 \mathrm{~nm}$ for flavan-3-ollike, $283 \mathrm{~nm}$ for flavanone-like, $325 \mathrm{~nm}$ for cinnamic acid-like, $330 \mathrm{~nm}$ for flavone-glycoside-like, $354 \mathrm{~nm}$ for flavonol-glycoside-like and flavanone-glycoside-like, $365 \mathrm{~nm}$ for flavone-like and $370 \mathrm{~nm}$ for flavonol-like compounds. The results were obtained from the average of three determinations and are expressed as $\mathrm{mg} / \mathrm{g}$ dried extract \pm percent relative standard deviation (\%RSD).

\section{Antioxidant activity \\ Free radical scavenging activity}

The free radical scavenging activity of $F$. vasta extract was evaluated using the DPPH (2,2-diphenyl-1-picrylhydrazyl) test, according to the protocol previously reported [17]. An aliquot $(0.5 \mathrm{~mL})$ of $80 \% \mathrm{MeOH}$ solution containing different amounts of the extract (0.0125-0. $2 \mathrm{mg} / \mathrm{mL}$ ) was added to $3 \mathrm{~mL}$ of daily prepared methanol DPPH solution $(0.1 \mathrm{mM})$. The optical density change at $517 \mathrm{~nm}$ was measured, $20 \mathrm{~min}$ after the initial mixing, with a model UV-1601 spectrophotometer (Shimadzu). Butylated Hydroxytoluene (BHT) was used as reference. The scavenging activity was measured as the decrease in absorbance of the samples versus DPPH standard solution. The results were obtained from the average of three independent experiments, and are reported as mean radical scavenging activity percentage $(\%) \pm$ SD. The results are also expressed as mean $50 \%$ Inhibitory Concentration
$\left(\mathrm{IC}_{50}\right) \pm$ standard deviation $(\mathrm{SD})$, determined graphically by interpolation of the dose-response curve; lower $\mathrm{IC}_{50}$ value indicates higher antioxidant activity.

\section{Measurement of reducing power}

The reducing power of $F$. vasta extract was evaluated by spectrophotometric detection of $\mathrm{Fe}^{3+}-\mathrm{Fe}^{2+}$ transformation method, as previously reported [18]. Different amounts of the extract $(0.0125-0.2 \mathrm{mg} / \mathrm{mL})$ in $1 \mathrm{~mL}$ solvent were mixed with $2.5 \mathrm{~mL}$ of phosphate buffer $(0.2 \mathrm{M}, \mathrm{pH} 6.6)$ and $2.5 \mathrm{~mL}$ of $1 \%$ potassium ferrycyanide $\left[\mathrm{K}_{3} \mathrm{Fe}(\mathrm{CN})_{6}\right]$. The mixture was incubated at $50{ }^{\circ} \mathrm{C}$ for $20 \mathrm{~min}$. The resulting solution was cooled rapidly, mixed with $2.5 \mathrm{~mL}$ of $10 \%$ trichloroacetic acid, and centrifuged at $3000 \mathrm{rpm}$ for $10 \mathrm{~min}$. The resulting supernatant $(2.5 \mathrm{~mL})$ was mixed with $2.5 \mathrm{~mL}$ of distilled water and $0.5 \mathrm{~mL}$ of $0.1 \%$ fresh ferric chloride $\left(\mathrm{FeCl}_{3}\right)$, and the absorbance was measured at $700_{\mathrm{nm}}$ after $10 \mathrm{~min}$; the increased absorbance of the reaction mixture indicates an increase in reducing power. As blank, an equal volume $(1 \mathrm{~mL})$ of water was mixed with a solution prepared as described above. Ascorbic acid and BHT were used as reference standards. The results were obtained from the average of three independent experiments, and are expressed as mean absorbance values $\pm \mathrm{SD}$. The reducing power was also expressed as ascorbic acid equivalent (ASE/mL); when the reducing power is $1 \mathrm{ASE} / \mathrm{mL}$, the reducing power of $1 \mathrm{~mL}$ extract is equivalent to $1 \mu \mathrm{mol}$ ascorbic acid.

\section{Ferrous ions $\left(\mathrm{Fe}^{2+}\right)$ chelating activity}

The $\mathrm{Fe}^{2+}$ chelating activity of $F$. vasta extract was estimated by measuring the formation of the $\mathrm{Fe}^{2}$ ${ }^{+}$-ferrozine complex, according to the method previously reported [18]. Briefly, different concentrations of the extract $(0.0125-0.2 \mathrm{mg} / \mathrm{mL})$ in $1 \mathrm{~mL}$ solvent were mixed with $0.5 \mathrm{~mL}$ of methanol and $0.05 \mathrm{~mL}$ of $2 \mathrm{mM} \mathrm{FeCl}_{2}$. The reaction was initiated by the addition of $0.1 \mathrm{~mL}$ of $5 \mathrm{mM}$ ferrozine. Then the mixture was shaken vigorously and left standing at room temperature for $10 \mathrm{~min}$. The absorbance of the solution was measured spectrophotometrically at $562 \mathrm{~nm}$. The control contains $\mathrm{FeCl}_{2}$ and ferrozine, complex formation molecules. Ethylenediaminetetraacetic acid (EDTA) was used as reference standard The results were obtained from the average of three independent experiments and are reported as mean inhibition of the $\mathrm{Fe}^{2+}$-ferrozine complex formation (\%) $\pm \mathrm{SD}$ and $\mathrm{IC}_{50} \pm \mathrm{SD}$.

\section{Protective effect on Escherichia coli under peroxide stress}

The ability of $F$. vasta extract to protect bacterial growth and survival from the oxidative stress induced by hydrogen peroxide $\left(\mathrm{H}_{2} \mathrm{O}_{2}\right)$ was evaluated according the protocol described by Smirnova et al. [19], with some modifications. 
Escherichia coli ATCC 25922 was obtained from the Department of Scienze Chimiche Biologiche Farmaceutiche ed Ambientali, University of Messina, in-house culture collection (Messina, Italy). Bacteria were grown overnight in LB medium. The overnight suspension was centrifuged (10 min at $3500 \mathrm{rpm}$ ), resuspended in LB fresh medium to obtain a final optical density at $600 \mathrm{~nm}\left(\mathrm{OD}_{600}\right)=0.1$, and then grown aerobically at $37^{\circ} \mathrm{C}$ with shaking at $150 \mathrm{rpm}$. In mid-log phase $\left(\mathrm{OD}_{600}=0.6\right)$ bacteria were centrifuged and the $\mathrm{OD}_{600}$ adjusted to 0.2 value with fresh medium. The bacteria suspension was then aliquoted and $F$. vasta extract $(1 \mathrm{mg} / \mathrm{mL})$ and reference standard quercetin $(0$. $2 \mathrm{mM}$ ) were added. Two control groups (Ctr), with and without $\mathrm{H}_{2} \mathrm{O}_{2}$ treatment, were included. After 30-40 min, when $\mathrm{OD}_{600}$ reached a value equal to 0.4 , in order to establish the ability of $F$. vasta extract to exert protection against $E$. coli growth inhibition induced from oxidative stress bacteria were treated with $\mathrm{H}_{2} \mathrm{O}_{2}(2 \mathrm{mM})$, and the growth was monitored every $20 \mathrm{~min}$ for $3 \mathrm{~h}$.

For survival studies, the bacteria $\left(\mathrm{OD}_{600}=0.4\right)$ were exposed for $30 \mathrm{~min}$ to a higher concentration of $\mathrm{H}_{2} \mathrm{O}_{2}(10 \mathrm{mM})$, which caused bactericidal effect. Then an aliquot of each sample was diluted in $0.9 \% \mathrm{NaCl}$ to obtain serial dilutions (1:10). Each sample was poured onto LB-agar plates and incubated at $37{ }^{\circ} \mathrm{C}$; after $24 \mathrm{~h}$ the number of viable colonies was counted to estimate the cell survival. The percentage (\%) of survival was calculated according to the formula: (colony forming units (CFU) of $\mathrm{H}_{2} \mathrm{O}_{2}$ treated culture/ CFU of untreated Ctr) $\times 100$ [20].

The results were obtained from the average of three independent experiments and are expressed as mean absorbance \pm SD and surviving (\%) \pm SD for protective effect on E. coli growth and survival, respectively. Statistical comparisons of the data were performed by Student's ttest for unpaired data. $P$-values lower than 0.05 were considered statistically significant.

\section{Artemia salina lethality bioassay}

The potential toxicity of $F$. vasta extract was investigated using brine shrimp (Artemia salina Leach) lethality bioassay, according to the method previously reported [21]. The extract was tested at different concentrations $(10-1000 \mu \mathrm{g} / \mathrm{mL})$. Ten brine shrimp larvae, taken $48 \mathrm{~h}$ after initiation of hatching in artificial seawater, were transferred to each sample vial, and artificial seawater was added to obtain a final volume of $5 \mathrm{~mL}$. After $24 \mathrm{~h}$ of incubation at $25-28{ }^{\circ} \mathrm{C}$, the vials were observed using a magnifying glass, and surviving larvae were counted. The assay was carried out in triplicate, and median lethal concentration $\left(\mathrm{LC}_{50}\right)$ values were determined using the probit analysis method. Extracts with $\mathrm{LC}_{50}$ higher than $1000 \mu \mathrm{g} /$ $\mathrm{mL}$ are considered non-toxic.

\section{Antimicrobial activity Microbial strains and culture conditions}

The following strains were used as indicators for the antimicrobial testing and were obtained from the Department of Scienze Chimiche Biologiche Farmaceutiche ed Ambientali, University of Messina (Italy), in-house culture collection: Bacillus subtilis ATCC 6633, Escherichia coli ATCC 10536, Escherichia coli ATCC 25922, Listeria monocytogenes ATCC 13932, Pseudomonas aeruginosa ATCC 15442, Salmonella typhimurium ATCC 13311, Salmonella enterica (Wild type), Staphylococcus aureus ATCC 29213, and Staphylococcus epidermidis ATCC 12228 were grown at $37^{\circ} \mathrm{C}$ in MHB; the yeast Candida albicans ATCC 10231 was grown at $35^{\circ} \mathrm{C}$ on SDA.

\section{Antimicrobial testing}

The minimum inhibitory concentration (MIC) and minimum bactericidal and fungicidal concentration (MBC and MFC) values of $F$. vasta extract were determined using the in broth microdilution method according to the protocols recommended by the Clinical and Laboratory Standards Institute [22, 23].

Cultures of bacterial strains and C. albicans were prepared overnight in MHB and RPMI 1640, respectively; microorganism suspensions were therefore adjusted with sterile medium to give $1 \times 10^{6}$ for bacteria and $1 \times 10^{4}$ $\mathrm{CFU} / \mathrm{mL}$ for $C$. albicans. The extract was dissolved in dimethyl sulfoxide (DMSO) (1\%) and MHB to obtain a final concentration of $1 \mathrm{mg} / \mathrm{mL}$. Two-fold serial dilutions were prepared in a 96-well plate. The tested concentrations ranged from 500 to $0.49 \mu \mathrm{g} / \mathrm{mL}$. The MIC was defined as the lowest concentration $(\mu \mathrm{g} / \mathrm{mL})$ of extract which completely inhibit the visible growth of microorganisms in broth after $24 \mathrm{~h}$ of incubation for bacteria and $48 \mathrm{~h}$ for C. albicans. All experiments were performed in triplicate on three independent days. Positive and negative controls were also included.

\section{Results \\ Phytochemical investigations \\ Identification of flavonoid compounds by paper chromatography}

Chromatographic separation of $F$. vasta extract allowed the identification of some flavonoid compounds, namely luteolin, quercetin, vitexin, quercetin-3-O- $\beta$-galactoside and rutin. Their structures were elucidated on the basis of, UV, ${ }^{1} \mathrm{H}-\mathrm{NMR}$, and MS analyses. The spectral information is summarized in Table 1.

Identification of phenolic compounds by HPLC-PDA/ESI-MS The quali-quantitative characterization of the phenolic compounds present in the $F$. vasta leaves extract was accomplished by HPLC-PDA/ESI-MS. Baseline compound separation was achieved on the employed fused-core 


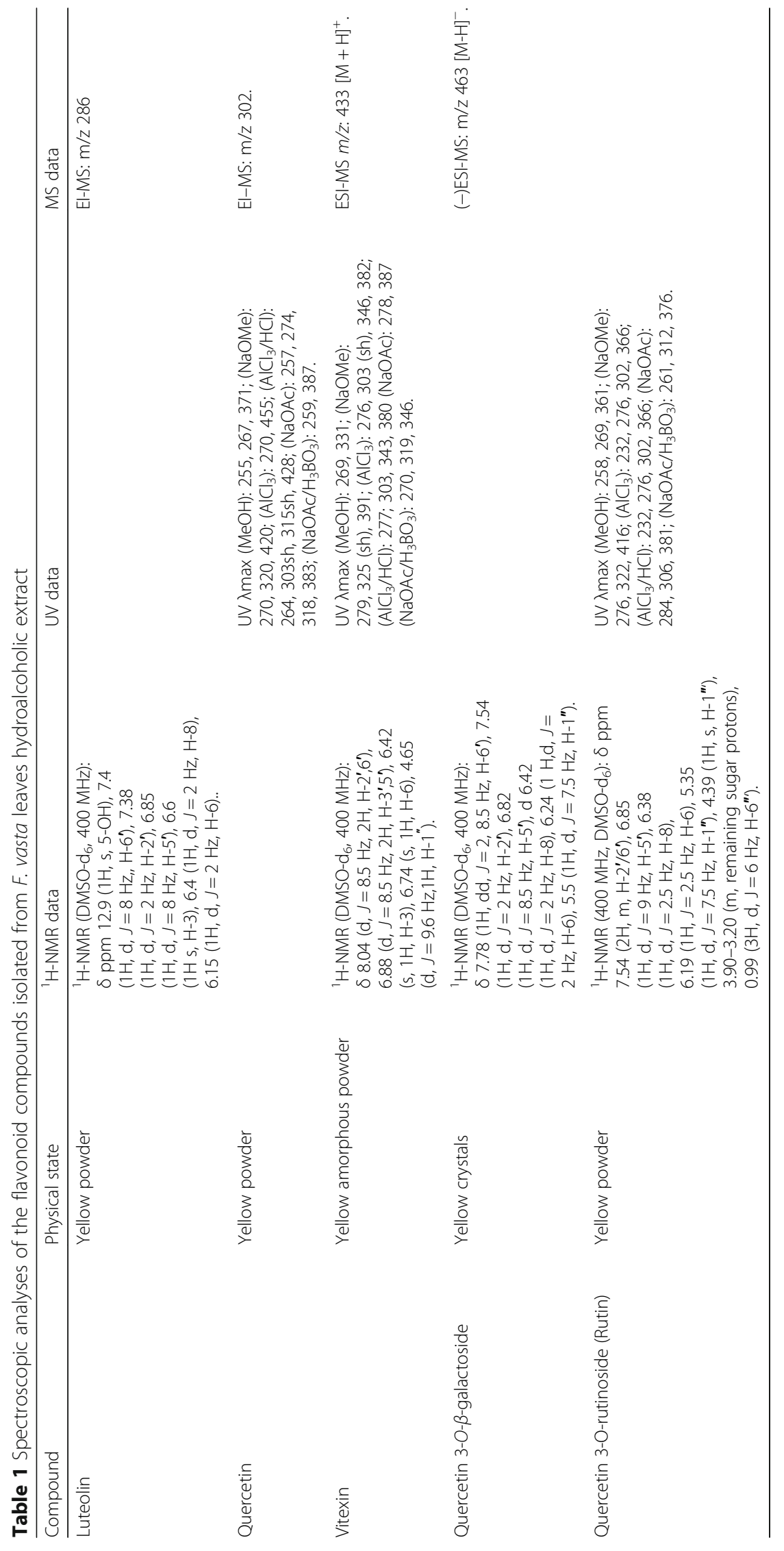


C18 stationary phase; as far as detection is concerned on-line coupling to PDA and MS detection provided complementary information for reliable identification purposes. The analysis revealed the presence of 12 compounds, 2 out of them belonging to the group of phenolic acids $(77.09 \mathrm{mg} / \mathrm{g}$ extract) and 10 to flavonoids (135. $98 \mathrm{mg} / \mathrm{g}$ extract). The flavonol quercetin-3-galactoside was found to be the main phenolic compound detected in the extract $(81.5 \mathrm{mg} / \mathrm{g} \pm 0.88 \% \mathrm{RSD})$, followed by gallic acid (76.36 mg/g $\pm 2.70 \% \mathrm{RSD})$ and isoquercitrin (22.5 mg/g $\pm 2.02 \%$ RSD) (Fig. 1, Table 2).

\section{Antioxidant activity \\ Free radical scavenging activity}

The results of DPPH assay are shown in Fig. 2a. F. vasta extract displayed strong radical scavenging effect, dosedependent, which reached about $90 \%$ inhibition at the concentration of $0.15 \mathrm{mg} / \mathrm{mL}$. The activity of the extract was higher than that of the standard $\mathrm{BHT}$, as indicated also by the $\mathrm{IC}_{50}$ values $(0.0672 \pm 0.0038 \mathrm{mg} / \mathrm{mL}$ and 0 . $0821 \pm 0.0009 \mathrm{mg} / \mathrm{mL}$, respectively).

\section{Measurement of reducing power}

F. vasta extract exhibited reducing power, that increased in a dose-dependent manner; the activity resulted lower than that of BHT, as confirmed by $\mathrm{ASE} / \mathrm{mL}$ values $(3.65$ $\pm 0.48 \mathrm{ASE} / \mathrm{mL}$ and $1.97 \pm 0.08 \mathrm{ASE} / \mathrm{mL}$ ) (Fig. 2b).

\section{Ferrous ions $\left(\mathrm{Fe}^{2+}\right)$ chelating activity}

In the $\mathrm{Fe}^{2+}$ chelating activity assay $F$. vasta extract showed mild, dose-dependent, effect (data not shown). As confirmed by the $\mathrm{IC}_{50}$ values, the chelating ability of the extract resulted much lower than that of the standard EDTA $(0.801 \pm 0.007 \mathrm{mg} / \mathrm{mL}$ and $0.0067 \pm 3.98 \mathrm{E}-$ $05 \mathrm{mg} / \mathrm{mL}$, respectively).

\section{Protective effect on Escherichia coli under peroxide stress}

In a preliminary experiment we established that $F$. vasta extract does not inhibit the growth of $E$. coli at the dose of $1 \mathrm{mg} / \mathrm{mL}$ under the experimental conditions utilized in this protocol, thus we tested the extract at the concentration of $1 \mathrm{mg} / \mathrm{mL}$ to evaluate its protective ability against the bacteriostatic and bactericidal effects of $\mathrm{H}_{2} \mathrm{O}_{2}$. As shown in Fig. 3, F. vasta extract displayed noticeable protective effect on $E$. coli growth under oxidative stress. Addition of $2 \mathrm{mM} \mathrm{H}_{2} \mathrm{O}_{2}$ resulted in a 60-min growth arrest of $E$. coli into the Ctr group. In the culture pretreated with quercetin $(0.2 \mathrm{mM})$, addition of $\mathrm{H}_{2} \mathrm{O}_{2}$ did not inhibit bacterial growth. The pretreatment with F. vasta extract $(1 \mathrm{mg} / \mathrm{mL})$ provoked a strong protection against $\mathrm{H}_{2} \mathrm{O}_{2}$-induced damage, statistically significant at all time points compared to Ctr group treated with $\mathrm{H}_{2} \mathrm{O}_{2}(P<0.001$ and $P<0.0001)$. Further, the cell growth of the culture treated with $F$. vasta extract notably exceeded that of quercetin group at 20, 40 and $60 \mathrm{~min}$.

The results of protective effect on $E$. coli survival are shown in Fig. 4. After $30 \mathrm{~min}$, an elevated loss of viability in the Ctr culture treated with $10 \mathrm{mM} \mathrm{H}_{2} \mathrm{O}_{2}$ (approximately $68 \%$ survival) compared to untreated $\mathrm{Ctr}$ was observed. In the culture pretreated with $F$. vasta extract, high survival (approximately 110\%) was maintained in the presence of $10 \mathrm{mM} \mathrm{H}_{2} \mathrm{O}_{2}$, statistically significant compared to $\mathrm{Ctr}$ culture treated with $\mathrm{H}_{2} \mathrm{O}_{2}$ $(P<0.0001)$; even in this case the observed effect was higher than that of quercetin.

\section{Artemia salina lethality bioassay}

F. vasta extract did not display any toxicity against brine shrimp larvae $\left(\mathrm{LC}_{50}>1000 \mu \mathrm{g} / \mathrm{mL}\right)$.

\section{Antimicrobial activity}

The antimicrobial properties of $F$. vasta extract were tested against a representative set of Gram-positive and Gram-negative bacterial strains and the yeast $C$. albicans, according to the protocols recommended by the Clinical and Laboratory Standards Institute [19, 20]. The MIC values of $F$. vasta extract are shown in Table 3.

After $24 \mathrm{~h}$ of exposure [20], the extract was effective against almost all the bacteria tested, with the exception of B. subtilis and P. aeruginosa (MIC > $500 \mu \mathrm{g} / \mathrm{mL}$ ). The extract showed higher efficacy towards Gram-positive than Gram-negative bacteria, with S. aureus and S. epidermidis being the most sensitive strains (MIC: $62.5 \mu \mathrm{g} / \mathrm{mL}$ ). None of the tested strains were inhibited by DMSO (maximum $0.5 \% \mathrm{v} / \mathrm{v}$ ), used as negative control (data not shown). The $\mathrm{MBC}$ values indicated that the inhibitory effect of $F$. vasta extract was bacteriostatic within the concentrations tested $(\mathrm{MBC}>500 \mu \mathrm{g} / \mathrm{mL})$. Finally, no activity was detected against $C$. albicans $(\mathrm{MIC}>500 \mu \mathrm{g} / \mathrm{mL})$.

\section{Discussion}

In this work we report for the first time the qualiquantitative characterization of the phenolic compounds present in the hydroalcoholic extract obtained from $F$. vasta leaves collected in Egypt. HPLC-PDA/ESI-MS analysis revealed the presence of phenolic acids and flavonoids.

Phenolic compounds are well known for their antioxidant properties by acting either as free radical scavengers, reducing agents or metal chelators [24]. Flavonoids and phenolic acids represent the largest classes of plant phenolics; phytochemicals from these classes were found to have excellent antioxidant activity in both in vitro and in vivo investigations [25].

Antioxidant activity, especially of phytocomplexes, cannot be evaluated satisfactorily by a simple antioxidant test, but it is strongly suggested the use of various methods in order to acquire a more complete antioxidant profile. In 


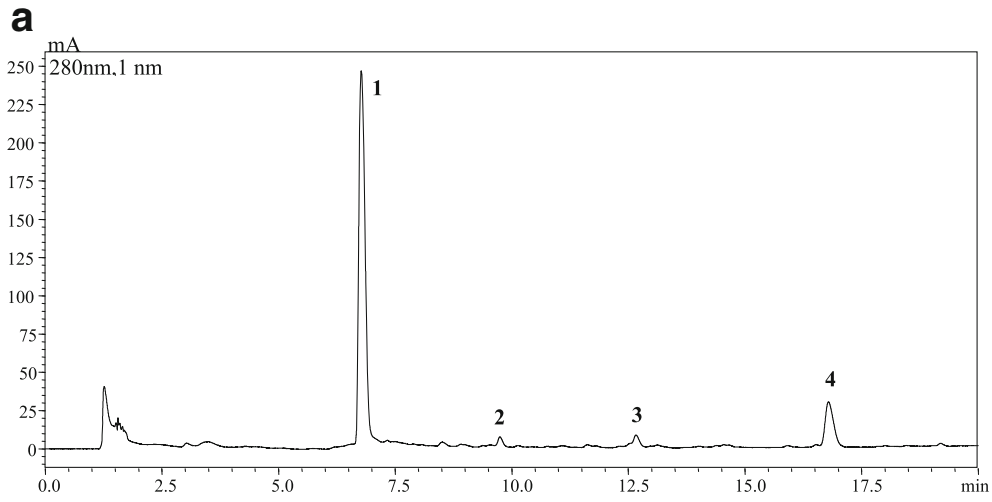

b

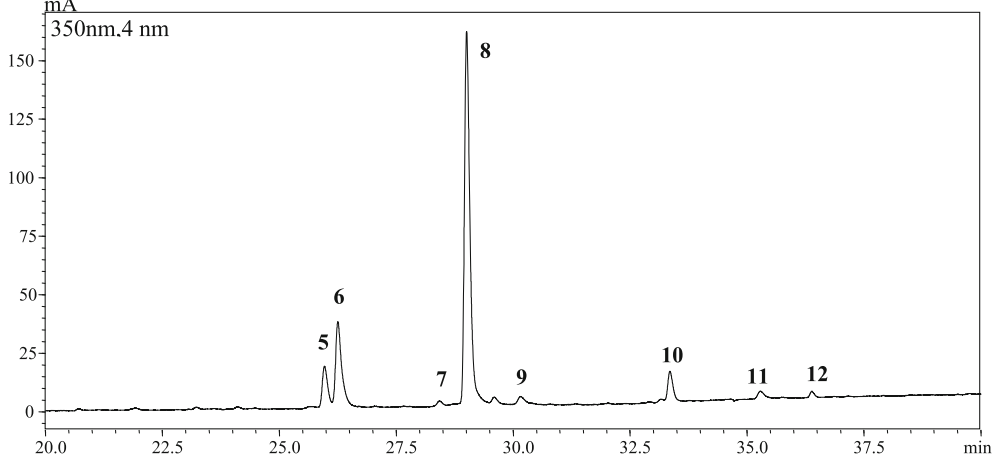

Fig. 1 HPLC-PDA chromatograms of the phenolic compounds, extracted at $280 \mathrm{~nm}$ (a) and $350 \mathrm{~nm}$ (b) wavelengths, of $F$. vasta leaves hydroalcoholic extract. For peak identification, see Table 2

these assays, plant extracts are generally assessed for their function as reducing agents, hydrogen donors, singlet oxygen quenchers or metal chelators, after which they are classified as primary (chain-breaking) and secondary (preventive) antioxidants [25]. Thus, three in vitro assays based on fundamentally different approaches and mechanisms were used to screen the antioxidant potential of $F$. vasta extract: the primary antioxidant properties were examined using the DPPH and the reducing power assays, and the secondary antioxidant ability was determined by measuring the $\mathrm{Fe}^{2+}$ chelating activity. Antioxidants can deactivate radicals by two major mechanisms: hydrogen atom transfer (HAT) and single electron transfer (SET); for $\mathrm{DPPH}$ test recently a combination of these two

Table 2 HPLC-PDA/ESI-MS (negative ionization mode) polyphenolic fingerprint of Ficus vasta leaves extract

\begin{tabular}{|c|c|c|c|c|c|c|c|c|}
\hline No. & $t_{R(\min )}$ & Molecular Formula & {$[\mathrm{M}-\mathrm{H}]^{-}$} & UVNis (nm) & Compound & Class & $\mathrm{mg} / \mathrm{g}$ extract & $\overline{\mathrm{RSD}(\%)}$ \\
\hline 1 & 6.8 & $\mathrm{C}_{7} \mathrm{H}_{6} \mathrm{O}_{5}$ & 169,125 & 210,270 & Gallic acid & Benzoic acid-like acid & 76.36 & 2.70 \\
\hline 2 & 9.7 & $\mathrm{C}_{15} \mathrm{H}_{14} \mathrm{O}_{6}$ & 289 & 205,278 & Catechin & Flavan-3-ol-like & 6.53 & 1.87 \\
\hline 3 & 12.6 & $\mathrm{C}_{16} \mathrm{H}_{18} \mathrm{O}_{9}$ & 353,191 & 215,325 & Chlorogenic acid & Cinnamic acid-like & 0.73 & 1.73 \\
\hline 4 & 16.8 & $\mathrm{C}_{15} \mathrm{H}_{12} \mathrm{O}_{5}$ & 271 & 283 & Naringenin & Flavanone-like & 5.84 & 1.30 \\
\hline 5 & 26.0 & $\mathrm{C}_{27} \mathrm{H}_{30} \mathrm{O}_{16}$ & 601,301 & 254,354 & Rutin & Flavonol-glycoside-like & 9.33 & 1.38 \\
\hline 6 & 26.2 & $\mathrm{C}_{21} \mathrm{H}_{20} \mathrm{O}_{12}$ & 463,301 & 254,354 & Isoquercitrin & Flavonol-glycoside-like & 22.50 & 2.02 \\
\hline 7 & 28.4 & $\mathrm{C}_{27} \mathrm{H}_{32} \mathrm{O}_{14}$ & 579,271 & 254,354 & Naringin & Flavanone-glycoside-like & 1.20 & 3.56 \\
\hline 8 & 29.0 & $\mathrm{C}_{21} \mathrm{H}_{20} \mathrm{O}_{12}$ & 463,301 & 257,354 & Quercetin-3-galactoside & Flavonol-glycoside-like & 81.75 & 0.88 \\
\hline 9 & 30.2 & $\mathrm{C}_{21} \mathrm{H}_{20} \mathrm{O}_{10}$ & 431,269 & 270,330 & Vitexin & Flavone-glycoside-like & 0.64 & 2.95 \\
\hline 10 & 33.4 & $\mathrm{C}_{21} \mathrm{H}_{20} \mathrm{O}_{11}$ & 447,285 & 256,346 & Kaempferol-3-glucoside & Flavonol-glycoside-like & 6.72 & 4.93 \\
\hline 11 & 35.3 & $\mathrm{C}_{15} \mathrm{H}_{10} \mathrm{O}_{7}$ & 301 & 370 & Quercetin & Flavonol-like & 0.98 & 0.81 \\
\hline 12 & 36.4 & $\mathrm{C}_{15} \mathrm{H}_{10} \mathrm{O}_{7}$ & 285 & 265,365 & Luteolin & Flavone-like & 0.49 & 3.31 \\
\hline
\end{tabular}

Column: Ascentis Express $\mathrm{C}_{18}, 15 \mathrm{~cm} \times 4.6 \mathrm{~mm}, 2.7 \mu \mathrm{m}$ d.p. (ESI, negative ionization mode; when observed, secondary fragment ions are reported).Values are expressed as the mean \pm S.D. $(n=3)$ 

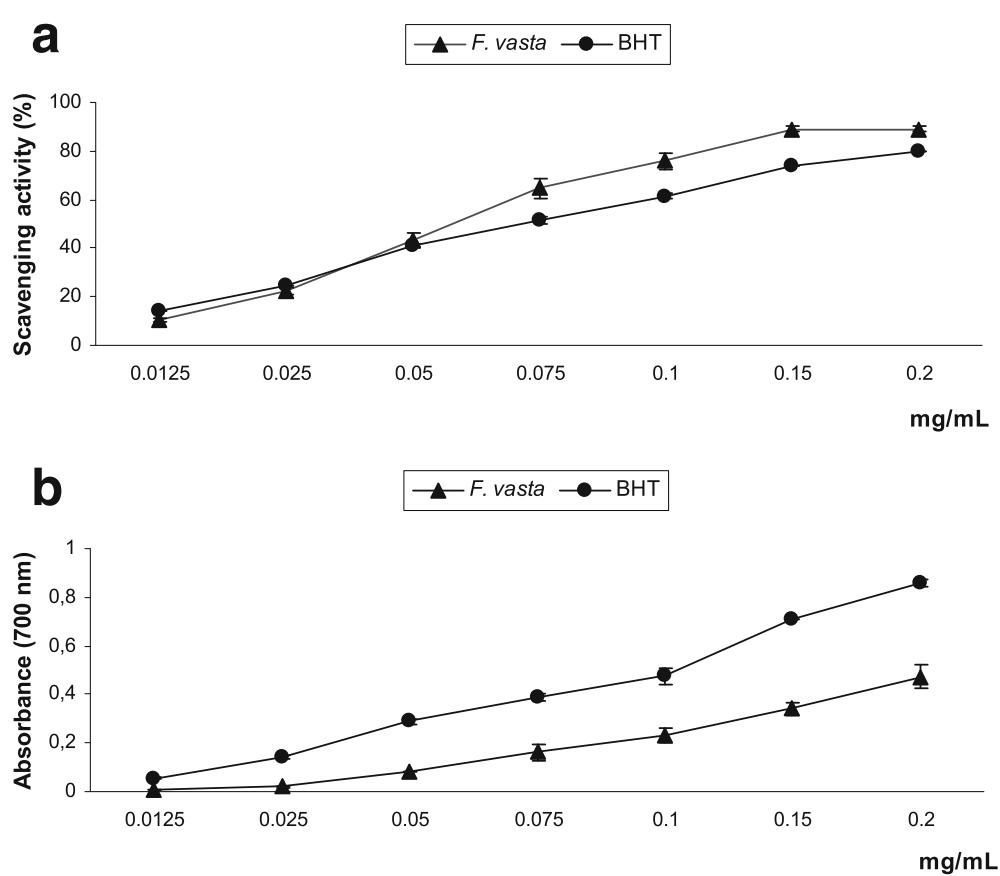

Fig. 2 Free radical scavenging activity (DPPH test) (a) and reducing power (b) of $F$. vasta leaves hydroalcoholic extract. Values are expressed as the mean \pm SD $(n=3)$

reactions, HAT and SET, was suggested to occur, whereas reducing power is recognized as electron transfer based method [25-27].

The results of antioxidant tests showed that $F$. vasta extract possesses primary antioxidant properties; these effects could depend mainly on the presence of flavonoids and phenolic acids, particularly quercetin3 -galactoside and gallic acid, which are present in high amounts in the extract. Previous studies demonstrated the strong radical scavenging properties of these compounds, as well as their ferric reducing ability [28-30]. Abdelwahed et al. [31] demonstrated that gallic acid adopt a hydrogen donating mechanism to scavenge the DPPH radical and it is even more effective than Vitamin E.
In order to investigate the antioxidant efficacy of $F$. vasta extract in a biological setting, the ability to protect bacterial growth and survival from the oxidative stress induced by hydrogen peroxide $\left(\mathrm{H}_{2} \mathrm{O}_{2}\right)$ was evaluated on Escherichia coli. This microbial model is utilized as an effective system to establish the antioxidant properties of medicinal plant extracts or pure compounds [32]; it is easier in terms of experimental operation, lower in cost compared to cellular antioxidant activity assays, and more biologically relevant than the in vitro measurements of antioxidant activity.

The obtained results showed that $F$. vasta extract displayed noticeable protective effects on $E$. coli growth under oxidative stress. These results are similar to those previously reported for different extracts of Potentilla

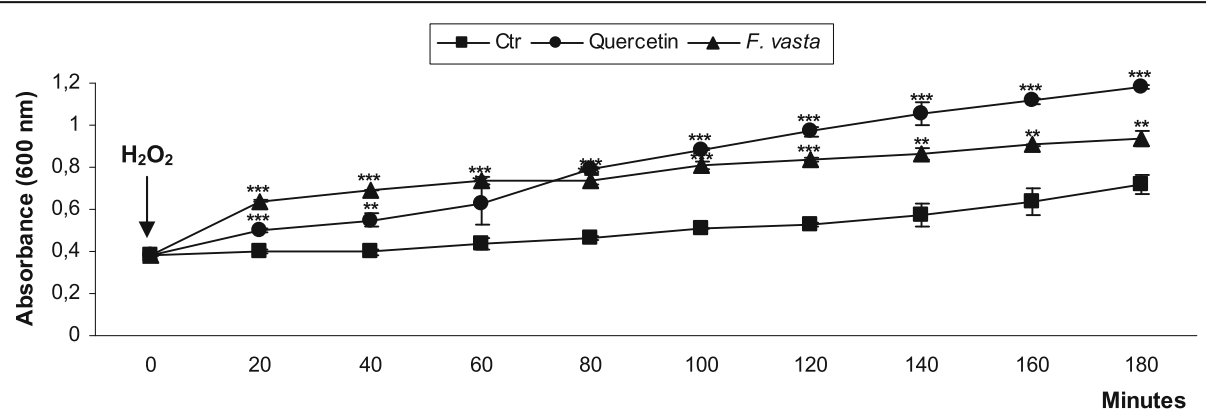

Fig. 3 Protective effect of $F$. vasta leaves hydroalcoholic extract on Escherichia coli growing under peroxide stress. Values are expressed as the mean $\pm \mathrm{SD}(n=3)$. Statistical differences compared to control group with $\mathrm{H}_{2} \mathrm{O}_{2}$ treatment $\left(\mathrm{Ctr}+\mathrm{H}_{2} \mathrm{O}_{2}\right)$ are noted with asterisk ( $\left.{ }^{* *} P<0.001,{ }^{* * *} P<0.0001\right)$ 


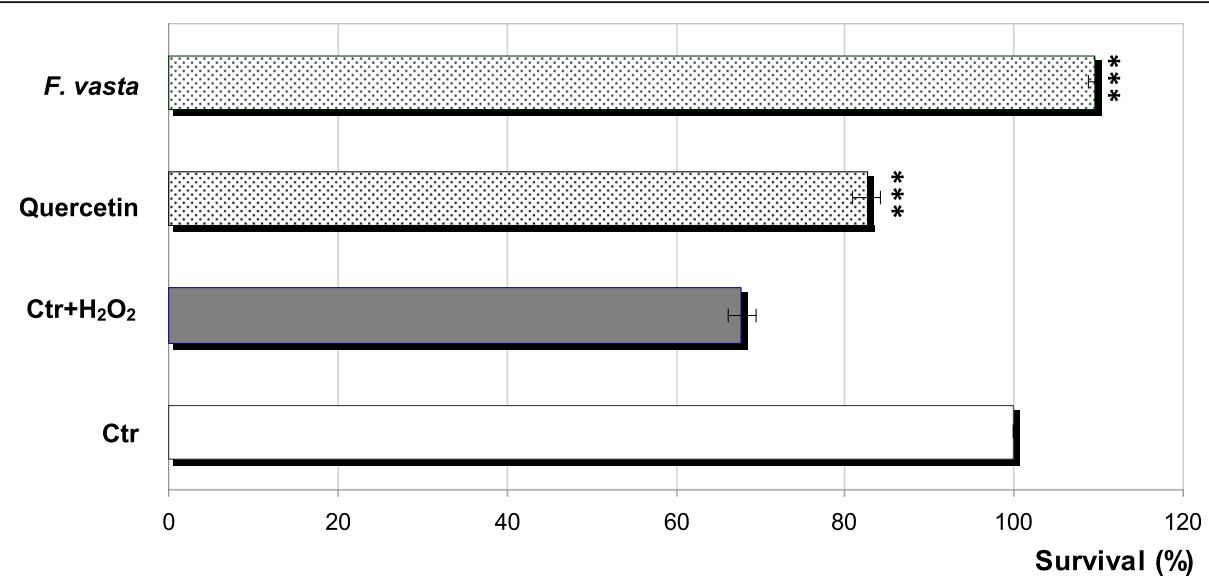

Fig. 4 Protective effect of $F$. vasta leaves hydroalcoholic extract on Escherichia coli survival under peroxide stress. Values are expressed as the mean $\pm \mathrm{SD}(\mathrm{n}=3)$. Statistical differences compared to control group with $\mathrm{H}_{2} \mathrm{O}_{2}$ treatment $\left(\mathrm{Ctr}+\mathrm{H}_{2} \mathrm{O}_{2}\right)$ are noted with asterisk ( $\left.{ }^{* * *} \mathrm{P}<0.0001\right)$

fruticosa L., tested at the same concentration of $F$. vasta extract and under the same experimental conditions [33]. Oktyabrsky et al. [34] previously demonstrated the protective effect of several plant extracts on $E$. coli survival in the presence of high concentrations of $\mathrm{H}_{2} \mathrm{O}_{2}$ $(10 \mathrm{mM})$; from a comparison of the results $F$. vasta extract showed a greater activity, displaying total protection against oxidative damage.

The protective effects of some polyphenols, as quercetin and catechin, on growth and survival of $E$. coli under peroxide stress has been previously reported [19]; thus, it can be hypothesized that the polyphenols contained in F. vasta extract are the main responsible for the observed activities.

In order to achieve a safe treatment with plant products, numerous research studies have recently been focused on the toxicity of medicinal plants. The brine shrimp (Artemia salina Leach) lethality bioassay has been established as a safe, practical and cheap method

Table 3 The MIC values of $F$. vasta leaves extract

\begin{tabular}{|c|c|}
\hline Gram positive bacteria & MIC $(\mu \mathrm{g} / \mathrm{mL})$ \\
\hline Bacillus subtilis ATCC 6633 & $>500$ \\
\hline Listeria monocytogenes ATCC 13932 & 125.0 \\
\hline Staphylococcus aureus ATCC 29213 & 62.5 \\
\hline Staphylococcus epidermidis ATCC 12228 & 62.5 \\
\hline \multicolumn{2}{|l|}{ Gram negative bacteria } \\
\hline Escherichia coli ATCC 10536 & 250.0 \\
\hline Escherichia coli ATCC 25922 & 250.0 \\
\hline Pseudomonas aeruginosa ATCC 15442 & $>500$ \\
\hline Salmonella typhimurium ATCC 13311 & 250.0 \\
\hline Salmonella enterica (Wild type) & 250.0 \\
\hline \multicolumn{2}{|l|}{ Yeast } \\
\hline Candida albicans ATCC 10231 & $>500$ \\
\hline
\end{tabular}

employed for preliminary assessment of toxicity and have been used for detection of fungal toxins, plant extract toxicity, heavy metals and pesticides [21]. According to Clarkson's toxicity criterion for the toxicity assessment of plant extracts, those with $\mathrm{LC}_{50}$ above $1000 \mu \mathrm{g} / \mathrm{mL}$ are considered as non-toxic [35]. F. vasta extract was found to be non-toxic against brine shrimps.

In the last decade, there has been growing interest in the use of plant extracts with low toxicity as sources of natural antimicrobial substances; particularly, the antimicrobial properties of plant extracts containing phenolic compounds were described [36-38].

F. vasta extract extract exhibited bacteriostatic activity against almost all the Gram-positive and Gram-negative bacteria tested, particularly against $S$. aureus and $S$. epidermidis.

Our results disagree with those of a previous work, which reported the lack of antibacterial properties of a $80 \% \mathrm{MeOH}$ extract of $F$. vasta aerial parts against $S$. aureus, S. epidermidis, E. coli and $P$. aeruginosa, as evaluated by the disk-diffusion method [13]; nonetheless, the extract was tested at the dose of $1.19 \mu \mathrm{g}$ only, and this could explain the disaccording results.

It can be hypothesized that the antimicrobial properties of $F$. vasta extract could depend on the presence of phenolic compounds. Gram-positive and Gram-negative bacterial species might have different sensitivities against the phenolics contained in $F$. vasta extract because of the difference in their membrane structure and associated cell wall differences. Many of the phenolic compounds were found to be effective against Gram-positive bacteria, whereas they showed no activity or negligible activity against Gram-negative bacteria. The partial hydrophobicity of some phenolic compounds allows them to act efficiently at the membrane-interface of Gram-positive 
bacteria, this causes the loss of membrane integrity and the dissipation of the proton motive force [39].

It is known that both flavonoids and phenolic acids are effective antimicrobial agents against a wide array of microorganisms [5, 40]. Liu et al. [41] previously reported that quercetin and luteolin showed a broad antimicrobial spectrum of activity on microorganisms including bacteria and fungi, whereas the glycoside derivatives such as quercetin 3-O- $\beta$-D-glucoside (isoquercitrin) exhibited relatively weak antimicrobial activity. Other authors showed that quercetin 3-O-glucoside didn't display any antibacterial efficacy [42].

The antibacterial activity of some phenolic acids such as gallic against Gram-positive (S. aureus and L. monocytogenes) and Gram-negative bacteria (E. coli and P. aeruginosa) was demonstrated; these compounds were found to be more efficient against the reported bacteria than conventional antibiotics such as gentamicin and streptomycin [43]. It was reported that gallic acid could restrain the growth of many bacteria, including methicillinsensitive $S$. aureus, MRSA, E. coli, P. aeruginosa, and $S$. typhi [44]. Based on these statements, gallic acid, contained in high amount in the extract, could be the main component responsible of the observed effects.

\section{Conclusions}

This study is the first report on the characterization of the phenolic profile and the evaluation of antioxidant and antimicrobial activities of the leaves of Ficus vasta Forssk. growing in Egypt. The results of our investigations showed that $F$. vasta extract possesses strong primary antioxidant properties, as well as antibacterial efficacy, particularly against the Gram-positive tested strains. Besides, the extract showed no toxicity against brine shrimp larvae.

These findings contribute to an increase in knowledge about this species, demonstrating the potential of Ficus vasta leaves as safe sources of natural antioxidant and antimicrobial compounds.

\section{Abbreviations}

ACN: acetonitrile; ASE: ascorbic acid equivalent; BHT: Butylated Hydroxytoluene; CFU: colony forming unit; DMSO: dimethyl sulfoxide; DPPH: 2,2-diphenyl-1-picrylhydrazyl; EDTA: Ethylenediaminetetraacetic acid; $\mathrm{H}_{2} \mathrm{O}_{2}$ : hydrogen peroxide; $\mathrm{IC}_{50}$ : mean $50 \%$ Inhibitory Concentration; LB: LuriaBertani; $L_{50}$ : median lethal concentration; MBC: minimum bactericidal concentration; MeOH: methanol; MFC: minimum fungicidal concentration; MHB: Müeller Hinton Broth; RSD: relative standard deviation; SDA: Sabouraud Dextrose Agar

\section{Acknowledgements}

The authors wish to thank the Foundation "Prof. Antonio Imbesi". The authors also gratefully thank Dr. Mohammed El-Gebaly, Department of Botany, National Research Centre (NRC) and by Mrs. Tereeza Labib, consultant of Plant Taxonomy at the Ministry of Agriculture and director of Orman Botanical Garden, Giza, Egypt, for identification of plant material.

\section{Availability of data and materials}

The datasets for supporting the outcomes of the study are included in the article.

\section{Authors' contributions}

MFT and NM designed the study and wrote the manuscript. KR, FC, PD, and LM carried out the phytochemical studies; MFT, NM, and RA performed the antioxidant and toxicity experiments; $\mathrm{AF}, \mathrm{CB}$, and $\mathrm{MD}$ the antimicrobial experiments. All the authors revised the article critically and gave approval of the final version.

Ethics approval and consent to participate

Not applicable.

Competing interests

The authors declare that they have no competing interests.

\section{Publisher's Note}

Springer Nature remains neutral with regard to jurisdictional claims in published maps and institutional affiliations.

\section{Author details}

${ }^{1}$ Dipartimento di Scienze Chimiche, Biologiche, Farmaceutiche ed Ambientali, University of Messina, Polo Annunziata, Viale Annunziata, 98168 Messina, Italy. ${ }^{2}$ Pharmacognosy Department, National Research Centre, 33 El-Bohouth st. Dokki, P.O.12622, Giza, Egypt. 'Foundation "Prof. Antonio Imbesi", University of Messina, Piazza Pugliatti 1, 98122 Messina, Italy. ${ }^{4}$ Dipartimento di Scienze Biomediche, Odontoiatriche e delle Immagini Morfologiche e Funzionali, University of Messina, Via Consolare Valeria, 98125 Messina, Italy. ${ }^{5}$ Scienze dell'Alimentazione e della Nutrizione Umana, Università Campus Biomedico di Roma, via Àlvaro del Portillo 21, 00128 Rome, Italy. ${ }^{6}$ Chromaleont s.r.l., c/o Dipartimento di Scienze Chimiche, Biologiche, Farmaceutiche ed Ambientali, University of Messina, Polo Annunziata, Viale Annunziata, 98168 Messina, Italy. ${ }^{7}$ Dipartimento di Scienze del Farmaco, sezione Biochimica, Viale Andrea Doria 6, 95123 Catania, Italy.

Received: 15 January 2018 Accepted: 17 April 2018

Published online: 16 May 2018

\section{References}

1. Acquaviva R, Menichini F, Ragusa S, Genovese C, Amodeo A, Tundis R, Loizzo MR, lauk. Antimicrobial and antioxidant properties of Betula aetnensis Rafin. (Betulaceae) leaves extract. Nat Prod Res 2013a;27(4-5):475-479.

2. Acquaviva R, Di Giacomo C, Vanella L, Santangelo R, Sorrenti V, Barbagallo L, Genovese C, Mastrojeni S, Ragusa S, lauk L. Antioxidant activity of extracts of Momordica foetida Schumach. Et Thonn. Molecules. 2013b;18(3):3241-9.

3. Hatami T, Emami SA, Miraghaee SS, Mojarrab M. Total phenolic contents and antioxidant activities of different extracts and fractions from the aerial parts of Artemisia biennis Willd. Iran J Pharm Res. 2014;13(2):551-9.

4. Dai J, Mumper RJ. Plant phenolics: extraction, analysis and their antioxidant and anticancer properties. Molecules. 2010;15(10):7313-52.

5. Cowan MM. Plant products as antimicrobial agents. Clin Microbiol Rev. 1999;12(4):564-82

6. Ahmed F, MKK A, Abedin Z, Karim AA. Traditional uses and pharmacological potential of Ficus exasperata Vahl. Sys Rev Pharm. 2012;3(1):15-23.

7. Abdel-Hameed E-SS. Total phenolic contents and free radical scavenging activity of certain Egyptian Ficus species leaf samples. Food Chem. 2009; 114(4):1271-7.

8. Alqasoumi SI, Basudan OA, Al-Rehaily AJ, Abdel-Kader MS. Phytochemical and pharmacological study of Ficus palmata growing in Saudi Arabia. Saudi Pharm J. 2014;22(5):460-71

9. Tkachenko H, Buyun L, Terech-Majewska E, Osadowski Z. In vitro antimicrobial activity of ethanolic extracts obtained from Ficus spp. leaves against the fish pathogen Aeromonas hydrophila. Arch Pol Fish. 2016;24:219-30.

10. Raju NJ, Yesuf EA, Bekele M, Wabe NT. Investigation of in vitro anthelmintic activity of Ficus vasta leaves. Asian J pharm Biol Res. 2011;1(4):454-8.

11. Mosa EO, Justin DD, Hamam SB, Mohamed EAO, Saad MHA. Evaluation of phytochemical and antimicrobial activities of some sudanese medicinal plants. World. J Pharm Pharm Sci. 2014;3(12):1769-76.

12. Rashed K, Anthonissen R, Cappoen D, Verschaeve L. Phytochemical composition and potential genotoxic effects of important Egyptian medicinal plants. Phcog Commn. 2015;5(3):207-16.

13. Rashed K, Ono L. Evaluation of cytotoxicity, anti-herpes simplex virus type 1 (HSV-1) and antibacterial activities of Ficus vasta and phytoconstituents. Int Curr Pharm J. 2013;3(1):211-8. 
14. Osman ME, Yassen HH, Deng JD, Mustafa RO, Hussein SM. General phytochemical screening and antioxidant activity of some Sudanese medicinal plants. J Forest Prod Ind. 2014;3(6):292-5.

15. De Souza KC, Schapoval EE, Bassani VL. LC determination of flavonoids: separation of quercetin, luteolin and 3-O-methylquercetin in Achyrocline satureioides preparations. J Pharm Biomed Anal. 2002;28(3-4):771-7.

16. Fathiazad F, Delazar A, Amiri R, Sarker SD. Extraction of flavonoids and quantification of rutin from waste tobacco leaves. Iran J Pharm Res. 2006;3:222-7

17. Taviano MF, Filocamo A, Ragusa S, Cacciola F, Dugo P, Mondello L, et al. Phenolic profile, antioxidant and cytotoxic properties of polar extracts from leaves and flowers of Isatis tinctoria L. (Brassicaceae) growing in Sicily. Plant Biosyst. 2017; https://doi.org/10.1080/11263504.2017.1338629.

18. Miceli N, Filocamo A, Ragusa S, Cacciola F, Dugo P, Mondello L, et al. Chemical characterization and biological activities of phenolic-rich fraction from cauline leaves of Isatis tinctoria L. (Brassicaceae) growing in Sicily, Italy. Chem Biodivers. 2017;14(8):1-11.

19. Smirnova GV, Samoylova ZY, Muzyka NG, Oktyabrsky ON. Influence of polyphenols on Escherichia coli resistance to oxidative stress. Free Rad Biol Med. 2009;46:759-68.

20. Schurig-Briccio LA, Farías RN, Rodríguez-Montelongo L, Rintoul MR, Rapisarda VA. Protection against oxidative stress in Escherichia coli stationary phase by a phosphate concentration-dependent genes expression. Arch Biochem Biophys. 2009;483:106-10

21. Taviano MF, Marino A, Trovato A, Bellinghieri V, Melchini A, Dugo P, et al. Juniperus oxycedrus L. subsp. oxycedrus and Juniperus oxycedrus L. subsp. macrocarpa (Sibth. \& Sm.) ball. "Berries" from Turkey: comparative evaluation of phenolic profile, antioxidant, cytotoxic and antimicrobial activities. Food Chem Toxicol. 2013;58:22-9.

22. Clinical and Laboratory Standards Institute (CLSI). Reference method for broth dilution antifungal susceptibility testing of Yeasts, 3rd ed. Approved standard M27-A3. In: Wayne (PA): clinical and laboratory standards institute; 2008.

23. Clinical and Laboratory Standards Institute (CLSI). Methods for dilution antimicrobial susceptibility tests for bacteria that grow aerobically, 9th ed. Approved standard M07-A9. In: Wayne (PA): clinical and laboratory standards institute; 2012

24. Chua LS, Hidayathulla S. Phytochemical profile of fresh and senescent leaves due to storage for Ficus deltoidea. Plant Biosyst. 2017;151(1):74-83.

25. Kasote DM, Katyare SS, Hegde MV, Bae H. Significance of antioxidant potential of plants and its relevance to therapeutic applications. Int J Biol Sci. 2015;11(8):982-91.

26. Prior RL, Wu X, Schaich K. Standardized methods for the determination of antioxidant capacity and phenolics in foods and dietary supplements. J Agric Food Chem. 2005;53:4290-302.

27. Csepregi K, Neugart S, Schreine M, Hideg É. Comparative evaluation of total antioxidant capacities of plant polyphenols. Molecules. 2016;21(2), 208:1-16.

28. Parejo I, Viladomat F, Bastida J, Schmeda-Hirschmann G, Burillo JS, Codina C. Bioguided isolation and identification of the non-volatile antioxidant compounds from fennel (Foeniculum vulgare mill.) waste. J Agric Food Chem. 2004;52(7):1890

29. Zhang $Y$, Wang D, Yang L, Zhou D, Zhang J. Purification and characterization of flavonoids from the leaves of Zanthoxylum bungeanum and correlation between their structure and antioxidant activity. PLOS ONE. 2014;9(8):e105725. 1-11

30. Badhani B, Sharma N, Kakkar R. Gallic acid: a versatile antioxidant with promising therapeutic and industrial applications. RSC Adv. 2015;5:27540-57.

31. Abdelwahed A, Bouhlel I, Skandrani I, Valenti K, Kadri M, Guiraud P, et al. Study of antimutagenic and antioxidant activities of Gallic acid and 1,2,3,4,6pentagalloylglucose from Pistacia lentiscus. Confirmation by microarray expression profiling Chem Biol Interact. 2007;165(1):1-13.

32. Smirnova GV, Vysochina GI, Muzyka NG, Samoylova ZY, Kukushkina TA Oktyabrsky ON. Evaluation of antioxidant properties of medical plants using microbial test systems. World J Microbiol Biotechnol. 2010;26(12):2269-76.

33. Yu D, Pu W, Li D, Wang D, Liu Q, Wang Y. Phenolic compounds and antioxidant activity of different organs of Potentilla fruticosa $\mathrm{L}$. from two main production areas of China. Chem Biodivers. 2016;13(9):1140-8.

34. Oktyabrsky O, Vysochina G, Muzyka N, Samoilova Z, Kukushkina T, Smirnova $\mathrm{G}$. Assessment of anti-oxidant activity of plant extracts using microbial test systems. J Appl Microbiol. 2009;106(4):1175-83.
35. Clarkson C, Maharaj VJ, Crouch NR, Grace OM, Pillay P, Matsabisa MG, Bhagwandin N, Smith PJ, Folb PI. In vitro antiplasmodial activity of medicinal plants native to or naturalized in South Africa. J Ethnopharmacol. 2004;92(2-3):177-91.

36. del Carmen Villalobos M, Serradilla MJ, Martín A, Ordiales E, Ruiz-Moyanoa S, de Guía Córdoba M. Antioxidant and antimicrobial activity of natural phenolic extract from defatted soybean flour by-product for stone fruit postharvest application. J Sci Food Agric. 2016;96(6):2116-24.

37. dos Reis Albuquerque AdJ, de Freitas e Silva PM, de Almeida Cavalcante ALF, Sampaiop FC. Polyphenols as a source of antimicrobial agents against human pathogens. In: Extracts P, editor. Giordano A, Costs A. New York (USA): Nova Science Publishers, Inc.; 2013. p. 275-94.

38. Bisignano C, Filocamo A, Faulks RM, Mandalari G. In vitro antimicrobial activity of pistachio (Pistacia vera L.) polyphenols. FEMS Microbiol Lett. 2013; 341(1):62-7.

39. Davidson PM. Chemical preservatives and natural antimicrobial compounds. In: Beuchat LR, Montville TJ, editors. Doyle MP. Food Microbiology. Fundamentals and Frontiers. Washington DC (USA): ASM Press; 2001. p. 611-6.

40. Cushnie TPT, Lamb AJ. Recent advances in understanding the antibacterial properties of flavonoids. Int J Antimicrob Agents. 2011;38(2):99-107.

41. Liu H, Mou Y, Zhao J, Wang J, Zhou L, Wang M, et al. Flavonoids from Halostachys caspica and their antimicrobial and antioxidant activities. Molecules. 2010;15(11):7933-45.

42. Razavi SM, Zahri S, Zarrini G, Nazemiyeh H, Mohammadi S. Biological activity of quercetin-3-O-glucoside, a known plant flavonoid. Bioorg Khim. 2009; 35(3):414-6

43. Daglia M. Polyphenols as antimicrobial agents. Curr Opin Biotechnol. 2012; 23(2):174-81.

44. Fu L, Lu W, Zhou X. Phenolic compounds and in vitro antibacterial and antioxidant activities of three tropic fruits: persimmon, guava, and sweetsop. Biomed Res Int. 2016;2016:1-9.

\section{Ready to submit your research? Choose BMC and benefit from:}

- fast, convenient online submission

- thorough peer review by experienced researchers in your field

- rapid publication on acceptance

- support for research data, including large and complex data types

- gold Open Access which fosters wider collaboration and increased citations

- maximum visibility for your research: over $100 \mathrm{M}$ website views per year

At BMC, research is always in progress.

Learn more biomedcentral.com/submissions 